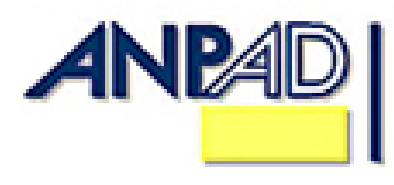

Available online at http://www.anpad.org.br/bar

BAR, Rio de Janeiro, v. 10, n. 3, art. 3, pp. 281-303, July/Sept. 2013

\title{
Gender and Work: Representations of Femininities and Masculinities in the View of Women Brazilian Executives
}

\begin{abstract}
Alexandre de Pádua Carrieri
E-mail address: aguiar.paduacarrieri@terra.com.br Universidade Federal de Minas Gerais - UFMG

UFMG/FACE/CEPEAD, Rua Curitiba, 832/1202, Centro, 30170-120, Belo Horizonte, MG, Brazil. Ana Paula Rodrigues Diniz
E-mail address: anaprdiniz@ @otmail.com
UFMG/FACE/CEPEAD, Rua Curitiba, 832/1202, Centro, 30170-120, Belo Horizonte, MG, Brazil.

Eloisio Moulin de Souza E-mail address: eloisiomoulin@gmail.com Universidade Federal do Espírito Santo - UFES Programa de Pós-Graduação em Administração/UFES, Av. Fernando Ferrari, 514, Goiabeiras, 29075-910, Vitória, ES, Brazil.

Raquel Santos Soares Menezes E-mail address: anaprdiniz@hotmail.com Universidade Federal de Minas Gerais - CEPEAD/UFMG UFMG/FACE/CEPEAD, Rua Curitiba, 832/1202, Centro, 30170-120, Belo Horizonte, MG, Brazil.
\end{abstract}

Received 30 May 2012; received in revised form 22 February 2013 (this paper has been with the authors for three revisions); accepted 4 March 2013; published online 21 May 2013. 


\begin{abstract}
The purpose of this article is to identify and analyze social representations of femininity and masculinity, as reported by women business executives in Brazil. For that, the research resorted to semi-structured interviews of sixty-four executives from seven Brazilian cities. As a technique for data analysis, this research utilized the theoretical and conceptual basis of French discourse analysis. When gender issues become related to the specific qualities of being a woman and a business executive - or to the interfaces that gender may establish with an individual's work - contradictions may emerge from the construction of a particular thematic. Also, positive and negative aspects of being a female executive exist, namely: (a) representations of an executive; (b) feminine competency and incompetency; (c) dilemmas regarding sensitivity; (d) conflicts involving seduction power; (e) omissions, prejudice and violence suffered by women at work; and (f) motherhood.
\end{abstract}

Key words: femininity; masculinity; business executive; gender; Brazil. 


\section{Introduction}

The purpose of this article is to identify and analyze social representations of femininity and masculinity as reported by women business executives in Brazil. Hence, the aim is to list this particular social group's characteristics and attributes, to determine those that are more or less valued in the corporate world, and to consider the consequences of such representations to the subjects involved, both women and men. The analysis of representations regarding certain subjects and objects can reveal the construction of femininities and masculinities through certain strategies and tactics within a political management model, while exposing social constructions around which a given social order lies.

Since the goal of this work relates to the representations of femininities and masculinities, it is worth clarifying what a representation means in this particular context. Representations are not simply descriptions that reflect workers' practices, but rather constitute and produce the workers' very practices (Louro, 2008). They are not a reflection of reality, but instead act as constructors of such: "From this perspective it should not be questioned whether a representation 'matches' reality or not, but since representations produce meanings, what should be asked what the effects of representations on individuals are and how they construct reality itself" (Louro, 2008, p. 99). Finally, as Louro (2008) emphasizes, representations are presentations; i.e., they are cultural means of categorizing, naming, and showing a group or individual. Louro (2008) makes clear that there is no such thing as pure world or reality that can be described or viewed through images that act as a true - or distorted - reflection of reality itself: there are always several representations and they all make sense.

Thus, the possibility that has been opened to women executives who stand out in a work environment clearly ruled by men indicates the construction of social representations of what a woman business person is. However, is there just a single representation? In this study, other representations of femininity and masculinity were sought, which might arise to resist and to counteract the hegemonic representation of women created and recreated by both men and women.

It is noteworthy that in this research femininity is not understood as merely a synonym for a woman (or women), neither is masculinity a synonym of man (or men). Instead, the two concepts relate to the historic, social, cultural, and spatial-temporal aspects involved and that, therefore, may present women and men as hegemonic (Gilligan, 1982; Halberstam, 1998). Research into gender helps understanding this issue, specifically in relation to Brazilian culture and labor conditions. In fact, it helps comprehend the Brazilian reality as a whole, since most research and authors on gender come from the northern hemisphere.

This research is organized in sections. The next section provides the theoretical framework and explores the following themes: a brief history of the discussions on gender and work, focused on the insertion of women in the work environments and the possibilities and limitations that this group has come across, including an overview of studies that focus on aspects of gender, femininity and labor in Brazil. This is followed by research methodology, analysis and conclusions.

\section{Gender and Women: a Social Construction}

Beauvoir's renowned work (2009) is used a starting point for this study, which expands upon the idea that women are constructed as the other in society. This concept implies, from a social standpoint, that the role of women is regarded as secondary and not as mere spectators, but as supporting figures behind great men who became part of human history. While great importance and even veneration have been given to motherhood at some moments in history, women have never been given an equal place or privilege compared to men. To Beauvoir (2009), men believe that humankind comes from their own image and women are perceived as the others. In other words, men represent the 
universal. Following Beauvoir's concepts (as cited in Braidotti, 2002) Braidotti's explanation that the price paid by men to represent universality is their very disembodiment, or the loss of gendered specificities to phallic masculine abstraction.

To understand how this social hierarchy is still operating in relationships between men and women, one can rely on the relational analysis of gender. This includes scholars such as Joan Scott (1986), who considered gender as a historical and relational category. From that perspective, the concept of gender brings the ability to give meanings to power relationships. Throughout the 1980s and 1990s, the influence of those categories - gender and power relations - has been increasing the quest for meanings related to sex/gender as a social construction, which in fact has become one of the main currents in feminist research.

Gardiner (2004) states that the most important accomplishment of feminist theory in the last century was the development of gender as a social construction. For the author, "masculinity and femininity are loosely defined, historically variable, and interrelated social ascriptions to persons with certain kinds of bodies - not the natural, necessary, or ideal characteristics of people with similar genitals" (Gardiner, 2004, p. 35). This accomplishment altered beliefs about the inherent characteristics of men and women. "The traditional sexes are now seen as cultural groupings rather than as facts of nature based on a static division between two different kinds of people who have both opposed and complementary characteristics, desires and interests" (Gardiner, 2004, p. 35).

In spite of the fact that contemporary feminist theory does not consider gender as a biological attribute, many gender authors still hold a binary concept of gender. For example, Irigaray (1985), when trying to counterpoint the binary gender view contained in Freudian psychoanalysis (which assigns superiority to men as a privileged social power visualized in the anatomy of males' sexual organ), states that Freud's phallogocentric concept of women's penis envy (castration anxiety) is a man's vulnerability and weakness. In fact, this is an ironic mirroring of Freudian ideas of women lacking genital equipment. In short, while trying to reverse the phallogocentric concept, Irigaray (1985) ends up reaffirming gender binarism. The poststructuralist approach intends to break with such a binary conception of gender.

Butler (2003) does not believe that sex belongs to the scope of biology and gender to the cultural one. The distinction between biological sex and cultural gender could suggest a radical discontinuity between sexed bodies and culturally constructed genders. Butler (2003) states that genders cannot be conceived only as a cultural record in a previously defined sex (a body), for gender must also designate the production mechanisms by which sexes themselves are established. Gender is something an individual becomes, but can never be, hence gender itself is a kind of process or activity. It should not be conceived as a noun or as a matter of substantive or cultural static label, but instead as an incessant and repeated action. If gender is not tied to sex, it is something that can grow beyond any binary limits.

Rubin (1984) has demonstrated the expression of masculinity in women's bodies, not only in men. For example, among lesbian individuals there are two categories, butch and femme, which establish an alternative genre system, for these are not the conventional imitation of female and male genres. Halberstam (1998) analyzed different varieties of masculinity in female individuals, defined by the author as masculinity without men, among them: the androgynous, the butcher, and the Drag King. Sedgwick (2008) clarifies that women are also consumers, producers and performers of masculinity. Thus, masculinity is not directly related to male individuals only. When masculinity is understood as a socio-historical construction, it leads one to a broader view of it, not limited to men studies; i.e., the biological sex. Women, men, gays, lesbians, and transsexuals, among others, are consumers, producers, reproducers and performers of these cultural products known as masculinity and femininity.

The hierarchical, unequal and asymmetric relationships between men and women have been justified by several instances that emerged from discursive practices, power structures, and symbols within a given organizational environment (Cramer, 2009). It is in the discussion on power that several 
studies find the origins of oppression in the socially constructed categories of male and female. Several studies show that within the construction process of power relations, gender relations are established and articulated. That is present in studies carried out in North America (Butler, 2003; Calás \& Smircich, 1999; Scott, 1992, 1998), Europe (Beauvoir, 2009; Bourdieu, 2007) and Brazil (Alonso, 2002; Cramer, Brito, \& Cappelle, 2004; Hirata, 2002; Louro, 1997, 2000; Nogueira, 2001; Z. L. C. Oliveira, 2005).

For Wittig (1985) gender is neither invariant nor natural, but a specifically political use of the category of nature, which serves the purposes of sexual reproduction. Anyway, for Wittig there is no reason to divide the human bodies into male and female and that division is appropriate for the economic needs of heterosexuality, for they attribute a naturalistic sense to its institution. Thus, for Wittig (1985) there is no such distinction between sex and gender, for the very category of sex brings along gender labels, is politically invested and naturalized, but not natural at all. For example, to Wittig (1985) lesbians are not women, for a woman is just a term that stabilizes and fosters the binary relation between men and women, when this relation is heterosexual. A study by Calás and Smircich (1999) is widely used to classify gender research in organizational studies. For the authors, from the intersections of femininity with the movements of class struggle, seven feminist theories can be highlighted, which are: radical, liberal, Marxist, socialist, psychoanalytic, post-colonialist, and poststructuralist (or post-modernist). Oksala (2011, p. 282) defends the importance of metaphysics to feminist theory. For the author, "Foucault is commonly read as shunning metaphysics in favor of historical analyses". This sentence tries to demonstrate that Foucault's thought in fact amounts to a radical politicization of ontology, while defending the importance of metaphysical inquiry in feminist philosophy.

While recognizing these limitations of the typology by Calás and Smircich (1999) and avoiding the limitation of a decisive classification for the research in question, this study derives from the understanding that we indeed live in a context that values masculinity. This status quo is characterized by an appreciation of the masculine over the feminine, which leads to the construction of social spaces with determinations and priorities based on sex and gender differences. As noted above, the construction of the rule established is through a collective action of socialization of biological differences or even the biologization of social matters. These lead to the belief that socially and historically constructed differences stem from biological ones and are therefore natural, or given.

Gardiner (2004) states the existence of alternatives to hegemonic representations of masculinity. Plummer (2004) points out that all men are not created equal and men who do not follow the conventional and hegemonic model of masculinity suffer discrimination and prejudice in the work. Therefore, not only are women discriminated against for gender motivations, but men are also. Gender operates as a system for suppression of both women and non-dominant men; i.e., it creates inequality not only among men and women, but also separately, within each genre. For instance, Ekenstam, Johansson and Kuosmanen (2001) have emphasized that social sanctions linked to the formation of masculinity highlight the importance of one of its alleged attributes, namely not failing, which creates widespread fear among men to become unsuccessful in life, whether it is in the sexual or professional scope. In this sense, Jerusalinsky (2005) stresses that masculinity is regarded as active whereas femininity is regarded as passive, in the collective imaginary.

Importantly, however, such a status valuing masculinity is not understood in this paper as a force that falls on individuals without leaving them a choice. Rather, it is developed from the assumption that such valorization is the result of a set of daily practices, which originates and perpetuates daily distinctions and gender inequalities. Moreover, it is noteworthy that although this study acknowledges the existence of masculinity valorization, it also acknowledges that such valorization is not experienced in equivalent manners in different contexts. It is argued that the gendered experiences faced by a European, white, upper-class woman in France is of a different order from that of a Hispanic, black, lower-class woman in Brazil. In this sense, the different ways involved in being a woman or a man can only be comprehended within a given context and in an interface that contain the other categories that may be relevant to the construction of subjectivities. The studies that analyze the influence of concomitant issues related to race, gender, age, social class, among others, are 
called intersectionality, and may be of either quantitative or qualitative nature. Rodriguez, RochaLawton and Gomez (2012) advocate the importance of the cultural dimension in intersectionality research, by studying the use of this concept to destabilize differences and discuss this current suitability as an analytical dynamics framework, in cross-cultural work settings. Bairley (2012) advocates the use of statistic scales for the study of intersectionality. Ambiguity, an inherent attribute of femininity, has gone beyond the religious scope and reached the professional field as well, as in the case of 19th century female historians. These women appeared in historiography - when mentioned and were presented as bright and even erotic and amateur, but in the long run they eventually became considered of having inferior education and little to offer to the lasting value of that profession. (Smith, 2003).

Consistent with these assumptions, femininity and masculinity is understood in this paper not as a synonym for an individual woman or a man, but instead as a historical, social, and cultural happening in the space-time. Moreover, these constructions are organized in hierarchies and exclusions and allow the formation of hegemonic representations of femininity and masculinity in certain contexts. Such representations are presented to subjects, both men and women, as an ideal model of woman/man. Hence, it functions as boundaries for the construction of subjectivity. In this sense, both men and women consume and produce concepts of femininity and masculinity; i.e., women show a mix of femininity and masculinity that redefine how women subjects shape themselves, as plural and distinguished from one another. Given this, this paper rejects gender determinism as a social structure upon which inequalities among men and women are based, within the scope of organizations. Furthermore, the universality of the woman executive model is also disregarded herein. Therefore, the existence of stable social structures in which the meanings of entities become universal cannot be regarded as certain (Calás \& Smircich, 1999).

\section{Gendered Work Relations}

From the Industrial Revolution on, the rationality allegedly connected to masculine figures has become highly esteemed at work. Thus, the discourses involving management and labor have generally associated masculinity to men, consequently legitimizing an ideal model of the male worker, who involves physical and behavioral aspects, as well as qualifications; this model has constituted a regime of truth of what workers should be like. As to the business world, Hansen (2002) states this has been an environment that praises masculinity. All concepts of work are crossed by gender differences and those functions perceived as masculine are seen as inaccessible to women (Hassard, Holliday, \& Willmott, 2000).

In the early nineteenth century, women's presence was concentrated in the wiring and weaving factories, since they were cheap and qualified labor. Throughout the twentieth century, women joined the global work force, which contributed to reduce the differences in market participation, especially in periods of rapid capital accumulation, such as World War II. However, the increased participation of women in business was disallowed not by an ideology of independence, but by the precarious economic situation and necessity to supplement their families' incomes (Beauvoir, 2009).

Hirata (2002) reports that $30 \%$ of all executives in Europe are women, and this is true for Brazil as well. However, from the total of women employed, only $10 \%$ manage to become executives and most of them have lower salaries and perform economically and socially devaluated activities. Regarding remuneration, the author emphasizes that French executives are paid an average of $24 \%$ less than men, but this difference is $19 \%$ in the factory worker category. Data from a 2008 International Labor Organization (ILO, 2008) report confirmed such discrimination, while highlighting that women belong to the most discriminated social group in the world, especially in organizations, in terms of hierarchical positions, remuneration, safety, and dismissal issues. For instance, Elsesser and Lever (2011) carried out an empirical research with 60,470 women and men and most participants reported a preference to have a male boss over a female one, including women 
themselves. While carrying out a theoretical review of several studies involving men and women in management positions, Merrick (2002) noted that: (a) the acceptance level in a masculine world and the better career opportunities for women may imply the adoption of male characteristics and behaviors, so as to become one of the boys; (b) there is a tendency by both male and female managers to hire and promote the same gender as theirs; (c) executive women may threaten male executives' wives in specific situations, such as on business trips; and (d) there is a general perception of males as being dominant, influential and effective, whereas women are regarded as submissive, resigned and influenced. The author concluded that men and women are treated differently at most companies, where they are systematically excluded from decision-making processes, due to the existence of gender stereotypes. Bobbitt-Zeher (2011) affirms that gender stereotyping is a discrimination predictor and suggests the importance of cultural, structural, and interactional influences on gender discrimination.

Cavazotte, Oliveira and Miranda (2010) analyzed the perception women have of gender inequality in the workplace and its consequences on their level of satisfaction and identification with the organization where they work, as well as the implications of these factors on the women's willingness to shut down organizations. According to the results, inequality does influence women's satisfaction and identification with organizations and affects the decision to change jobs.

The management field relates to issues of gender and work. The concept of a worker as being a white male has permeated the academic field of management and organizational studies (Collinson, 1992; Hansen, 2002). Gender differences highlight a position's status, conception, and the division of tasks. The binary and biological view of gender that attributes femininity as something belonging to women, and masculinity to men, contributes to the division of tasks between men and women. Although women may assume different roles in the labor market, men hold most positions regarded as important. The work aspects, from their very conception, are perceived as being male or female, and the roles assigned to men immediately exclude women (Hassard et al., 2000). Business administration, according to those scholars, is a field marked by male domination. In that sense, Mavin, Bryans and Waring (2004) argue that the logic of rationality shows male influence, which makes organizational aspects to reflect gender relations. For example, Cappelle and Melo (2010) investigated the operational activity of women in the Military Police of the Brazilian state of Minas Gerais. Women who were admitted into the organization carried out mostly office activities, that is, administrative tasks and public relations. Women who, in turn, wished to exercise operational activities usually faced many obstacles. Given this, in order for women to be considered as field officers, they need to refrain from all typically feminine conduct or trait and "act as heroines, in the sense of the term virile" (Cappelle \& Melo, 2010, p. 96).

According to Kanan (2010), much is said about women as workers, however, women's performance as leaders in commanding positions is hardly discussed. In fact, Kanan (2010) conducted a study on female performance in leading organizations, in order to contribute to gender and work discussions, which consequently smoothed out the differences attributed to women workers. For Kanan (2010, p. 255), "the rejection of male hegemony brings about a new path for women: not only to take power in their hands, as authoritarian and oppressive before, but in a sense of renewing the concept that power must be shared and democratic". Thus, "even if women executives are excluded from promotions or employ all their abilities to perform their activities, the success views for positive results will transcend race, gender, sexual orientation, among other things that segregate minorities" (Kanan, 2010, p. 255). 


\section{Aspects on Gender and Labor in Brazil}

For this study, it is necessary to consider, however, the basis upon which Brazilian society is organized. Men were placed in charge of the household (Davel \& Vasconcelos, 1997), while outlining, in this sense, the initial boundaries of an alleged space of representation for women who were part of a traditionally male universe. The construction of the labor market over the centuries has reproduced the secondary role of women in Brazilian culture, for the occupations involving women labor were inferior and subordinate (Figueiredo, 2002). 18th century women were part of the labor market as dressmakers, confectioners, spinners, lace-makers, cooks, laundresses and housekeepers, and shared with men tasks such as baking, weaving and tailoring; women stood out in trading as well, and were named negras de tabuleiro (black women who sold their goods on the streets of the colonial towns and villages).

In Brazilian organizations, it can be observed that women continue to play subordinate roles compared to predominantly male chief managers, as a consequence of male power over women (Davel \& Vasconcelos, 1997; Freitas, 2001; Nader, 2002). Women's advancements in work hierarchies are far from being egalitarian: besides getting lower remuneration than men and battling to ascend in the hierarchy, women have come across power issues, opposition, or even male indifference. However, in the scope of women's activity in the Brazilian labor market in recent years, Bruschini and Puppin (2004) point out that it is distinguished by continuities as well as changes. On one hand, the continuities concern the still large number of women who join the labor market in less favorable or precarious positions or who are limited to work in segments traditionally regarded as feminine, such as nursing and teaching. On the other hand, the changes involve the expansion of women employment in prestigious professions, such as those in fields like Medicine, Architecture, Law, and even Engineering, which until not long ago were exclusively reserved for males.

However, Brazil women have conquered higher education level than men, but, in spite of the high level of education, Brazilian women are part of the pyramid base when it comes to the financial resources assigned to them by their professional activity (Natividade, 2009). In addition to that, lower wages, unemployment, changes in family structure, poor working conditions, high participation in the informal market, among other issues, are all barriers originated from gender aspects in the development and implementation of public policies regarding egalitarian women participation in the labor market.

A study carried out by Bruschini and Puppin (2004) with women executives and managers in various business sectors discovered that the factors that contribute to the selection of women to senior positions in organizations are: hard work; education; assignment to specific work positions; and corporate culture. The authors also concluded that many women are assigned to areas such as marketing and customer relationship due to the association between femininity and sensitivity and intuition. According to the respondents, a woman's feeling may be useful in several situations in the field of corporate management and even more importantly, women should know how to control rationality, an ability normally associated with men, with their maternal side, but without losing their senses of discipline, responsibility, intuition, and persuasion.

Similarly, authors such as Melo (2001, 2003), N. Oliveira, Oliveira and Dalfior (2000) and Segnini (1997) emphasize that Brazilian companies have regarded women as a differential asset, while taking advantage of different perspectives and styles as competitive edges in the so-called global market. Those authors have undertaken research on gender, especially in banks, and identified distinguished features in female management style, such as communication; sensibility; intuition; flexibility; persuasion; affection; and agility.

According to Corrêa (2004) and Tanure, Carvalho and Andrade (2007) one of the tools that women have resorted to in order to narrow the gaps generated by prejudice and social discrimination is to behave as men, since it is necessary to adopt a masculine style of management to advance in organizational hierarchy. This can be inferred to result in a loss of diversity corresponding to the 
masculinization of management. Concomitantly, an alleged feminine style of management, more intuitive and emotional, is also mentioned.

Silveira (2009) conducted another study on this subject, with the goal of analyzing inequality of conditions for inclusion of women and men in the organizational environment. Contemporary organizations have a more diverse demographic profile. However, this diversity does not mean that all individuals feel equally included in the work environment. For the author, the inclusion of different cultural identity groups has been perceived as a tool for leveraging advantages, such as competitiveness, creativity and diversity for consumers. However, such a discourse does not promote an appreciation of differences; but on the contrary, it seeks to eliminate them through training. Thus, women, even when inserted in organizations, face barriers to their inclusion due to gender role and manager stereotypes (Silveira, 2009). In that same direction, Ragins, Towsend and Mattis (1998) report on the necessity of women taking on strategies to be accepted, which include forms of defeminization. Scholars such as Corrêa (2004), N. Oliveira et al. (2000) and Vilas Boas, Paula and Cramer (2003) note that the promotion process remains slower for women and claim there are still barriers to greater equality, such as lower wages and a higher rate of unemployment, as compared to male individuals. In this sense, these scholars believe that the old conditions of discrimination have only been attenuated.

Discrimination against women in the workplace is not an isolated social phenomenon, but it is mixed in with other types of discrimination. The study conducted by the authors showed that women feel discriminated due to the following reasons: holding inferior hierarchical positions than men, even when they have higher qualification; undergoing higher demands from their superiors in case they are married with children; the practice of male-chauvinist behavior from bosses and co-workers; and the discourse and attitude imposed by males on their way to professional ascension or success.

Most of these works mentioned here regard femininity as meaning a female individual and masculinity a male individual. Souza, Corvino, and Lopes (2011) points out that this approach is used by most Brazilian organizational researchers and therefore such studies assume a biological concept of femininity and masculinity. In other words, these investigations strengthen the natural aspect of gender as something biological and not only socially constructed. Why should one not study femininity in men and masculinity in women? Why should one consider women as the only gender to be discriminated against?

Eccel and Grisci (2009) came up with an innovative approach to the gender aspect in the field of Brazilian organizational studies. Analysis was carried out from the perspective of masculinity, as considered from oral interviews of male and women workers of a large company. The authors suggest that "shifting one's look to male gender reveals that not only women go through challenges in their integration, ascension and permanence in corporate environments, since behavior parameters and expectations are established for male individuals as well" (Eccel \& Grisci, 2009, p. 14). This approach follows the post-structuralist perspective and its main contribution is a view on power and hierarchy relations among masculine ideals that underlie beliefs, ideas and representations of what is valued in a given context.

According to Eccel and Grisci (2009), in this articulation of gender and power it is acknowledged that the distribution of power is affected by gender aspects, which, in turn, are involved in the very conception and construction of power. The studies based on that perspective focus on the subjective processes that construct femininity and that underlie the view of both men and women.

\section{Methodological Framework}

In the effort to reach an understanding of the phenomena studied, it is necessary to have a comprehension that emerges from within the phenomenon itself. In other words, it is not adequate to 
define general parameters or simple linear causality among variables, while dethroning the meanings given to the phenomena by actors and subjects who experience concrete daily life activities. This refers to the qualitative research tradition, which studies, among other things, the social sciences' shifts towards the ontological and epistemological epicenter, as opposed to the quantitative. Goldenberg (2002), for instance, asserted that the main difference between the method of quantitative and qualitative research lies in the fact that the first provides an understanding of the phenomenon, while the second seeks to establish universal rules and laws, therefore forming parameters that can generalize knowledge forms.

Data collection was primarily carried out in seven cities, all state capitals in southern and southeastern Brazil. They were: Belo Horizonte, Brasília, Porto Alegre, Rio de Janeiro, Salvador, São Paulo and Vitória. This fact increased the diversity about the corpus and the possibilities to understand the knowledge on the various representations of femininity. These cities were selected because of the network established among the central research group responsible for this research, with other research groups located in these cities.

A semi-structured interview guide was used on women managers and entrepreneurs, and women in direction positions in the industry and service sectors, both public and private. For Thiollent (1987) semi-structured interviews are a strategy to introduce the researcher to the cultural universe of the studied subjects. These interviews were based on only one support guide in order to allow greater flexibility in dealing with issues and with the respondents themselves. At the end of the process of data collection, 64 interviews were gathered.

The researchers used the snowball concept to perform the interviews. In this process, the participants indicated other potential people to be interviewed. The total number of interviews was not defined a priori and the closure of the data collection depended on the saturation of the interviews concerning the phenomena studied in this research. Each interview last between 50 and 106 minutes. The interviews were realized after scheduling them with the respondents and occurred in places chosen by the women interviewed in agreement with the interviewers.

After the data collection, all interviews were transcribed to facilitate data analysis. What company the respondents belong to, nor any personal information that can facilitate their personal identification, is disclosed in the research. The respondents were given random names that have no real connotation with their individual names to keep them anonymous. Thus, they were named using codes from E01 to E64.

Roughly, the group of women participants was aged 31-60 years-old (average 45 years-old). Half of the respondents are married and have two children or less. The other half of the respondents consisted of 22 women who declared to be divorced (and having two children or less as well) and 10 single women, without children. Most respondents (45 of them) occupy the position of directors and middle managers and claimed to be executives. The research also included, on a small-scale, women entrepreneurs, owners of their companies, who also self declared to be executives. 43 respondents are from private sector and the remainder works in the public sector. Most respondents work in large companies and 52 women interviewed have a man as their boss. One-third of them have undergraduate degrees in management and all of them have attended graduate school. Half of the remaining twothirds who were not management majors have some specialization in management.

This study specifically sought to understand how the signifiers shared among women hold the notions of femininity and masculinity. The idea was to analyze the internal differences of the signifiers pointing out internal differences, highlighting the different signs produced by the same signifier that support what comes to be the image of femininity and masculinity in the corporate world.

The transcriptions were analyzed using discourse analysis, more specifically French discourse analysis. Discourses construct and are constructed by the social world and they do not necessarily refer to spoken or written language. This breaks with the traditional anthropological position of subject. Thus, we cannot see the discourse as something done, finished, fixed and static entities, neither as 
something that has an essence. This technique is extremely valuable to the analysis of the construction of femininity signifiers shared by women executives. The use of discourse analysis was an attempt to analyze the social world constructed by the subjects who experience these events.

Gill (2002) states that there isn't an analysis of discourse, but many types of analysis and what different styles of analysis share "is a rejection of the notion that realistic language is simply a means of reflecting neutral, or describe the world, and a belief in the centrality of discourse in the construction of social life" (Gill, 2002, p. 244).

It is known that discourse analysis was incorporated as a critique of positivist approaches, which caused tremor in the social sciences, and it is also widely used by structuralism and post-structuralism (Potter, 1996). For Gill (2002) there are 57 forms of discourse analysis. Therefore, this variety makes it almost impossible to trace the epistemological differences between them. Thus, to facilitate an analysis of the epistemological differences between discourse analysis, Gill (2002) notes that there are three theoretical traditions that characterize epistemologically the most usual forms of discourse analysis: (a) critical linguistics, (b) ethnomethodology/speech act theory/conversation analysis and (c) post-structuralism.

In this sense, discourse analysis as carried out in this paper relates to the post-structuralist perspective, apart from the critical linguistics. In fact, according to Gill (2002) linguistic criticism is grounded in structuralism and semiotics. Newman (2005) suggests that structuralism holds central the idea that experience and reality is primarily structured through language relations; i.e., we understand ourselves and the world around us through an external linguistic structure that determines meanings. For the author, structuralism is a new form of essentialism or foundationalism in which identity was again found in an absolute ground.

However, post-structuralism is not a homogeneous approach. About this aspect Adler, Forbes and Willmott (2007) believe that there are various forms of post-structuralism. The authors emphasize that the common feature among poststructuralist approaches is the concern with the critical role of language in organizing and performing our relationship with the world. Thus, post-structuralism radicalized the basic insight that there is no independent observation of language, rejecting the claim that there is an objective truth. All truth is contingent on power relations. What post-structuralism tries to combat the most is the search for essences and structures (Adler, Forbes, \& Willmott, 2007).

Newman (2005) believes that post-structuralism does not reject structuralism per se, but radicalized it. Post-structuralism does not abandon the idea that identities are discursively constructed by external relations, but avoids the essentialism and foundationalism, while questioning the unity, consistency and stability of signifiers.

For Foucault (2003a), discourse is not a structure, but an event and, therefore, belongs to the historical order. According to Foucault (2003a, p. 56) "The fundamental notions that are needed now are no more the continuity, the consciences ..., the sign and the structure. They are the event and the series". Thus, for Foucault (2003a, p. 57) the notions that are linked to a given event are regularity, causality, discontinuity, dependence and transformation. Discourse is something rare, discontinuous, regular, finite and material. In this sense, for Foucault (2003a), statements are historical contingences and they make sense because they manifest the social context that produce them, this being the main difference between discourse analysis and content analysis.

Foucault (2003a, p. 10) states that "the discourse is apparently very little, the interdictions that it suffers show its connection with the desire and the power". For Foucault (2003a) there is not a single truth about discourse, but instead, truth regimes that make speeches something contingent, rare and finite. This means to say that Foucault (2003b) does not believe that there is a hidden/implicit truth waiting to be discovered in the discourse. For Foucault (2003a) one statement has several discourses that allow it to be interpreted in various ways. Incidentally, the truth does not exist for the author, as his discourse analysis is an analysis of the surface and not of the depths, as hermeneutics is carried out seeking implicit or hidden meanings. The search for meanings implied claims that "there is truth itself 
accessible by the perception of history or there is a discipline that has a neutral discourse that can reveal this truth" (Dreyfus \& Rabinow, 1995, p. 36). This can be exemplified in Foucault's (2003b) analysis of scientific discourse:

Since Foucault argues that what counts as truth is determined by the conceptual system, or more precisely, by the discursive practices of a specific discipline, it does not make sense for him to say that a particular theory of the sciences is true or false (Dreyfus \& Rabinow, 1995, p. 33).

Foucault (2003b, p. 255) states that "What interests me in the discourse problem is the fact that someone said something at a given time. That isn't the sense that I seek to show, but the function that can be assigned once this thing was said at that time". Hence, Foucault (2003a) "is not interested in the way which a local context, pragmatically, and a plea of non-discursive practices determines conditions of satisfaction of discursive acts" (Dreyfus \& Rabinow, 1995, p. 53). Therefore, "the statement can be understood by a listener reporting it as being true in the sense that there is no need to refer to the family context in which the statement was made" (Dreyfus \& Rabinow, 1995, p. 53).

Foucault (2003a) preaches the end of the reign of the signifier established in structuralism. Saussure saw language in terms of a system of linguistic signs composed of signifier and signified. For Saussure the signifier does not have internal instability or internal difference, this means that the signifier has just one fixed signified and there are differences just among signifiers. Exactly at this point Foucault (2003a) asserts that there is no necessary relation between signifier and signified. In other words, for Foucault the signifier has internal differences that affirms its internal instability producing internal differences. This breaks with the structuralist belief that structures are so totalizing and determining that they could be seen as a new form of essentialism and truth. In this research, we found and analyzed six main signifiers: executive, competence, sensitivity, seduction, violence and motherhood. Consistent with Foucault's (2003a) ideas we analyzed the different meanings produced around these signifiers, showing their internal differences.

In the same way the "concept of ideology has been rejected by both Foucault and Deleuze, who saw it as involving essentialist and rationalist assumptions" (Newman, 2005, p. 10), Foucault (2004, p. 7) says that the "notion of ideology seems hardly usable for three reasons. The first is that it is always in virtual opposition to something that would be the truth.... Speeches are neither true nor false". Regarding the other two reasons, Foucault $(2004$, p. 7) states that the second and third drawbacks of the ideology is that it "necessarily refers to something like the subject. Finally, ideology is in a secondary position with respect to something that should work as an infrastructure or economic determination".

Gregolin (2004) clarifies that the statements are not oral speeches or phrases to Foucault, because maps can be understood even when not subjected to a linguistic structure. The statements are not speech acts, because they don't intend to seek material act (speaking / writing) or the intention of the individual who is performing the act, nor the result. Statements are not propositions because "unlike the preposition, the statement is in the level of discourse and therefore cannot be subjected to the tests of true / false" (Gregolin, 2004, p. 24).

\section{Representations of Women Executives in the Discourse of the Respondents}

These next pages are dedicated to analyze the interviewed executives' discourses. It is important to specify that the respondents' discourses were organized into six groups of subjects. These subjects emerged from discourse analyses of the women executives: (a) representations of an executive; (b) feminine competency and incompetency; (c) dilemmas regarding sensitivity; (d) conflicts involving seduction power; (e) omissions, prejudice and violence suffered by women at work; and (f) motherhood. 


\section{The representations of an executive}

The first semantic route comprehended consists of the representations as to what an executive should be, regardless of the relationship established with genders. In other words, such a route is delineated from the general idea built by the research subjects about what the executive function consists of; i.e., the attributes that, in their view, would not be framed by gender differences. As representations, we find the commander, the noble, and the political. It is important to note that, as it is a characteristic of the construct discussed in this paper, representations are concepts around which in addition to common sense - are established conflicts, contradictions and disputes. In this sense, the representations are characterized by negativity and positivity, for approximations of the subjects towards what is expected - or believed to be expected - of this particular position.

The representation of the executive as a commander is initially outlined from the need for formal and tacit knowledge for the practice of that profession. As E26 states: "for sure, I think that today, if you want to be an executive, you must have education, a lot of it, as well as experience". E52 states that "Because I have a task that is managing a business, and managing a small business, but I have this great challenge of making this little business to become big... So inevitably, I need to apply the knowledge of administration, and I have to use it as best as possible. And this has to be a professional activity. And I treat my business in an extremely professional way, applying all the techniques I know, getting informed, trying to improve my knowledge and learning. I don't want to stop. I want to continue studying, doing another graduate degree to act in a professional manner".

We see, therefore, the centrality of formal knowledge as a defining attribute of executives. Moreover, Natividade (2009) showed us that Brazilian women valorize high levels of education. It is interesting to observe the defense that executive positions are not for everyone and the censorship of a recurrent practice: the opening of businesses by people who are not prepared. In that sense, the subjects' speeches arguably have in between their lines a valuation of management skills, which are often put to question, and the establishment of a market reserve, in so far as to restrict the space for certain professionals. Then, it can be observed that the executives interviewed give great value to technical rationality (Mavin, Bryans, \& Waring, 2004). In other words, they believe that rationality and technical knowledge are the most important key for success and achievement, as stated by E25: "I have friends who want to open a business and say: 'Look, E25, I will not open a business because it came out in a research that out of all businesses set up every year, $\mathrm{X}$ go bankrupt in the first year, $\mathrm{X}$ in the second, $\mathrm{X}$ in the third. So most of business that are established will shut down in a few years'. But that's the thing. Why do they go bankrupt? Because some of their managers are not executives, but rather adventurers who are working, but not exercising a function, a profession. These managers are not doing their business as a profession”.

In the speeches analyzed, other types that were found to be the related to the ideal executive are the manager and the entrepreneur. These figures are related to the representation of the commander as well. E48 claimed to be a manager, considering that "a businessperson is whoever owns a company." Regarding executives, they are described as "the ones who think" and distinguished them from managers, who are "those who make things happen and sells an idea for a team", with the latter being more related to operational aspects. The excerpt implies an identification of executives with the planning and strategic sectors of business, as well as a certain detachment from the operational aspects of the very paths they have outlined. A separation between the conception and the actual realization of a given task can be inferred. From that perspective, the executive would be in charge of the first, especially in terms of being responsible for the strategic planning.

What relationships are there between commander representation and gender? First, the valuation of rationality and technical knowledge manifests in how the interviewed executives depreciate aspects related to emotion, sensibility, feelings, and tenderness (Tanure, Carvalho, \& Andrade, 2007). They consume and produce aspects perceived as masculine in Brazilian culture. We need to keep in mind that masculinity, as a constructed cultural product, does not belong to man and it is not solely produced by men. Women are producers and consumers of masculinities as well, as Rubin (1984), Halberstam (1998), and Sedgwick (2008) described. Therefore, it is important to understand gender as 
a cultural product and not as something biologically determined. This paper disagrees with the idea contained in Merrick (2002), for example. Merrick (2002) believes that women need to become a man or one of the boys to occupy high organizational levels. Merrick's affirmation is based on the concept that masculinity is directly related only to men and does not consider women as producer of masculinities. Moreover, as Eccel and Grisci (2009) state, not only women have challenges to their integration and ascension in corporate environments, since masculine behavior parameters and expectations are established for men as well.

Hansen (2002) affirms that the business world has been a world that praises masculinity and not men. We need to understand that organizational environments, also as societies, value the hegemonic masculinity (Gardiner, 2004), and both men and women that do not perform hegemonic masculinity are discriminated against in society (Ekenstam, Johansson, \& Kuosmanen, 2001; Plummer, 2004).

The need for self-image management and the attention paid to a certain posture established to executives, as pointed out by E18 and E45, are reaffirmed by E61 as impositions. According to that respondent, executives are perceived as representatives of the companies. However, such a representation is full time, or extended to moments when these individuals are not working or even during leisure time. The executives need to act as politicians, as occupants of a public position, because there are not borders between their private and public lives. There is an implied idea that any flaw by executives is inexcusable and shall cause problems not only to them as individuals, but also to the organization that they represent. Such imposition of a determined image and posture model becomes even more rigid regarding physical traits, as was mentioned on the second excerpt. Excess weight is identified as a mismatch with the function occupied by the subjects, which establishes a status that can be perceived as an act of violence. Similarly, E21 discusses the difficulties involved with the need to fit the formal posture demanded of executives, the imposed standards and stereotypes associated with not only one's professional profile, but also behavior and body expression, among others.

Another representation of negativity associated with the noble representation of executives refers to the idea of superiority or prestige assigned to this particular position: the noble. Respondents E23, E43 and E48 make such matters explicit. The alleged superiority and prestige of executives are present not only in the way they dress, but mainly in their own perception of superiority. Consequently, they do not get involved with others and with the organization's processes in a broader participation in the operational aspects. The non-involvement with such takes place due to the noble status held by executives and to a certain lack of preparation, as is mentioned at the end of the speech excerpt. This discourse was found in the words by entrepreneurs, too. E20 states that "some people want to be entrepreneurs because they think it is cool to be an entrepreneur, they want to have a jet of their own, they would like to live shuttling, they want to arrive in a place and to be recognized". Although an initially positive image of executives is built, by mention of their extensive knowledge and strategic thinking, the respondent assigns to these very traits a detachment from people and processes. This makes the negative side of knowledge clear and the consequent detachment is perceived through the metaphor of an organizational god, created by the dehumanization of such individuals. In fact, E6 mentions this: "I think the executive has the idea to be supreme. Interviewer: And how would you describe the executive? If you could describe a picture ... a picture... that person is very well dressed, that person has a very high degree of acquired knowledge, because he will think strategically. And a person who is not involved in both processes. Almost a ghost image of an organizational 'god'”.

When gender issues are brought about and related to the specificities of being a woman executive or to the interfaces that the genre establish with work, it is important to note that while inserted into a binary order, these women must refer to how they perceive masculinity and femininity. The themes presented in the next section will corroborate this idea. 


\section{Feminine competency and incompetency}

If masculinity is something valued in organizations, what is the representation and space occupied by femininity? The theme that constitute this trajectory refers to the gender skills perceived as feminine and which may contribute for work performance, as well as the characteristics that may impair it. In this sense, this theme is composed of the competences and incompetence attributed to femininity. First of all, the feminine is not the opposite of the masculine. Masculinity and femininity are constituted together. Moreover, femininity contains masculinity in the same way that masculinity does not exclude femininity.

As key favorable attributes at work, women's carefulness and tact are observed. Such characteristics can be understood as the ability to settle troublesome situations without creating conflicts. As stated by E13, "the thing is that women often have this catching our breath thing, leave the situation alone so as to get back to it in a different way. Women have been trained for that, I think, to not lash out at men". The excerpt emphasizes that female carefulness in solving conflicts is placed not as a biological derivation, but instead as a result of women's socialization, as made explicit by the word trained. In this way, despite the fact that masculinity is the gender aspect most valorized in the work, some characteristics related to femininity are praised too and seen to be important abilities in the management field. This has been described by Melo (2001, 2003), N. Oliveira et al. (2000), Segnini (1997), and Bruschini and Puppin (2004).Carefulness and conflict solving are also presented by the other respondents. E21 also highlights keen intuition, beyond the obvious perception, as a positive aspect in women executives' performance: "I'll tell you that women usually tend to do a 'look, take a look, think twice before doing it'. I think women have more understanding about what people want to say between the lines, you know you are having a dispute there. So, you do not need to engage in the dispute, but act in the direction that the dispute does not increase".

Some respondents even consider female carefulness as a means of self-control. Another feature related to carefulness and tact is flexibility. E46 stated that the "sense of how to deal with other people" is perceived as a female attribute. It is something that men often try to develop, as they realize the contributions that this feature offers to management and related activities. Thus, the attempt to impose oneself, men's intolerance, is seen as a masculine attribute and something negative that leads nowhere. The female's perception, however, is seen as positive, such as fostering good relationships and helping in managing everyday work situations. Moreover, the respondents deepen the discussions on executives as being perfectionists.

The ability to be organized is emphasized by the respondents and is linked to feminine attribute capacity to perform several tasks at once. To be able to perform several tasks concurrently is presented as something typically feminine and that can contribute to the execution of a job that demands dynamism. As the main axes of allegedly feminine characteristics, the carefulness aspect can be observed, which unfolds into tact, self-control and flexibility. In addition, there is the ability to be organized and carry out multiple tasks simultaneously, which leads to perfectionism and versatility. Accordingly, a reference to the feminine style of management can be detected, supporting the arguments of authors such as Bruschini and Puppin (2004), Melo (2001, 2003), N. Oliveira et al. (2000) and Segnini (1997), which have emphasized certain qualities associated with females that have been considered as differential assets in the business world, as previously mentioned. About flexibility, the respondents believe that less flexibility is a masculine attribute that is not a good characteristic to executives in their everyday work. E48 said: "I think men are not only proactive, but I think if they were a bit more flexible ... men tend to not be so malleable.... they're tough, they're pushers, they must be. And because of that, they face difficulties".

\section{The dilemmas regarding sensitivity}

Female sensitivity was one of the most emphasized theme in the respondents' speeches. Much as with the other themes, sensibility has a dual, ambiguous character. On the one hand, this is viewed positively, as an attribute that favors dynamism and the work as a whole. The importance attached to 
this characteristic is even more prominent when placed against executives' pragmatism, which would lead to disrespect and dehumanization. E4 affirms that the "question about male objectivity, women don't have it, women tend to understand more, they care more about people, what people will think about how she makes a decision. Men use fire and sword .... I think (women's) sensitivity helps because at the same time that I suffer with it I seek to put myself in someone else's position.... I think the woman is, is more accurate than the man. So I can identify if a person, that their day is not good, even by just their voice". On this regard, E49 states that "I always joke that there are so many different women, there's some women that I joke that they look like men. That's what I told you, they are more rational, slower; I think these are the most negative aspects, less dynamic, but they are more rational, more logical". E11 believes "that sensitivity is the strongest characteristic. It allows us to perceive situations that men would not give importance to and that can sometimes be harmful at work".

On the other hand, as shown previously, sensibility is seen as something negative, as if it were a kind of emotion that could undermine the profession. In this sense, there can be detected an excessive personalization of professionals' relationships, loss of focus and objectivity required to work, and the difficulty of imposing oneself and acting aggressively in certain situations. The discourse by E11 serves as an example of the negative side of sensibility related by the interviewed women: "The only problem women have happens when they permit the emotional side to speak louder. That is the downside ... that people are very emotional, most of us are very emotional. That's what damages us". Then, if on one hand sensitivity is seen as something positive for work, on the other hand this attribute is perceived as excessive emotionalism, which unfolds in several other negative aspects. The first of these would be the weakness of women, portrayed by respondent E40. The subject constructs two distinct female characters: the woman with masculine traits, who is able to handle the pressure and divide professional issues from personal ones; and the frail woman, who cries when under pressure and who gets a little downhearted or is too sensitive. Interestingly, despite the stress that some women are subject to at work, the respondent expects every woman to be weak, as can be assumed from "some of them even surprise themselves in that matter", not knowing that they show these characteristics.

Emotion is perceived by the respondents as something antagonistic to objectivity and pragmatism, present in masculinity. The respondents also highlighted that objectivity is something that may be present in women and derives from an individual's own work and willpower, as suggested by the fragment "when she wants to be objective" (E23). For women executives, personality in relationships could possibly be expressed by the consideration of affection at the expense of professional relationships.

\section{Conflicts around seduction power}

Female stereotypes can also be seen in the discussion on women seduction powers, an attribute that is placed as an alleged female competence within organizations, but that also hides contradictions and conflicts, much like the other characteristics pointed out. The positivity of seduction supposedly resides in the greater ability to captivate and involve other individuals. E41 makes explicit women's ability to relate to both sexes, while men interact best with other men. E6 emphasizes the ability to captivate customers by pampering them, a capacity that doesn't exist in men, given their pragmatism and objectivity.

The duality of seduction in the scope of labor is explicit. This is because, at the same time that a certain amount of seduction is endowed to women it is also seen as a facilitator for customers' approach and attraction, implicit in the expression breaking the ice. Moreover, when exacerbated, seduction may suggest disruption of the boundary between what is formal - the workplace - and informal - the scope of personal relations, particularly sexual ones. The quote "this can be understood otherwise by a customer" (E19) implies that male customers may interpret a woman's attitude as something sexually suggestive. In this sense, the respondent ponders about how problematic the question of seduction in the work environment is and emphasizes that women's ability to seduce men and men's formality are perhaps not so generic. This would suspend the fact that such characteristics 
do not constitute something given, but instead a recurrence. E29 affirms: "Forget the sensuality, play the role of friend, confidant, but never sensual. Because the sexy ... will lose the customer, he/she will never buy anything else again. Or he/she will ask for a discount that does not exist, because he/she gave you a gold earring, gave you a car. E8 also states that: "the woman needs to learn how to behave, you know?... So you have to have a serious attitude, you need to have an attitude of respect, you have to respect too". Regarding this matter, subject E26 states that "I never used low necklines and such, but I always dress femininely.... So I dress normally, but I do not exaggerate the feminine aspect".

Hence, there is an ambiguity that pervades the use of seduction in the work environment. At the same time that it is placed as something that promotes leadership, coordination of team members, and improvements in customer relationship, it is also seen as the inclusion of sex in an inappropriate scope, which is the work universe. When related to the other inferred representations, one can see the opposition between women's two representations. Therefore, in accordance with Smith (2003), there is an ambiguity associated with femininity, born in the sphere of the organizational field, and still reproduced in the professional field.

\section{The omissions, prejudice and violence suffered by women at work}

This fact implies for women a greater need wear revealing clothing, especially clothes worn at work (Tanure et al., 2007), which, as already emphasized, is understood here as an act of violence. This is even more evident due the occurrence of sexual harassment in organizations, which has been exposed by Freitas (2001). This context emphasizes the fact that women are not regarded as victims of harassment and are placed as those responsible for the violence they suffer. The harasser, most often a man, thus comes off clean and his aggression is placed as a mere reaction to women's irresponsibility, as though they demanded to be attacked. In this sense, the findings by Freitas (2001) are corroborated, in terms of the social stigma that still falls on victims of sexual harassment, who are often blamed for the violent act. The discourse of E62 can illustrate this matter: "So, for example, I had a situation I vividly remember, it happened at a bank. I had a meeting with the director and his team. I was going there to criticize him and his team decisions that they were trying to implement. And he knew it. So when I arrived, he put his hand on my shoulder and said: 'Hey, old lady, let's go out tonight and have a blast.' He said it in front of everyone. I turned to him and said: 'Come on, you invite your wife, I will call my husband, no problem, what time?"”.

The existence of masculinity hegemony- which stems from an appreciation of what is masculine at the expense of what is feminine - and the prejudice and violence triggered by it are present in the respondents' statements, for they show how women are seen as feminine and because that they are still neglected in the organizational environment. More than that, it is evident how organizations fulfill the role of (re)producing society's hierarchies and marginality in a broader sense, reserving inferior places for women and what is feminine as E17 affirms that "I needed to deal with a company that is usually managed by men, with owners and managers are men. So, then, they had some kind of prejudice against opening an account with a woman, and letting a woman manage their account at the bank. The other managers also said: "no, let me go, because that client, (who is a man), I get along well with him, I can chat with him ..., and do something to land them as a customer".

It can be inferred from the oral accounts how neglecting their femininity distinguishes women respondents' trajectories in work environments. As discussed by the respondents, there is a context of appreciation of man over woman, in which men are chosen by other men (Merrick, 2002) and they are placed as more assertive, competent and appropriate for executive positions, even when women prove to be more qualified for the activity. For example, E23 stated that "I took part in selection processes where men were chosen against any arguments ..., I participated in situations where Joseph and Mary competed as equals and Joseph was chosen because he was male. But he was chosen by other men.... Sometimes the women compete with equal competences with a man and the man is chosen because he is male". 
In business, as well as in broader society, men remain at the top of the social hierarchy because they are seen as guardians and representing masculine values, power holders and privileges compared to other subjects (Cappelle \& Melo, 2010; Collinson, 1992; Corrêa, 2004; Hansen, 2002). Hence, neglection of women leads to exclusions in the organizational environment, as well as the struggle against barriers.

\section{Motherhood}

Women, due to the context of male domination in which they are inserted, face many obstacles in organizations. Among these, the interviews highlighted maternity or difficulties arising from being a mother. These unfold in difficulties related to both the insertion or ascension to higher positions and to accumulation of roles as a professional and a mother.

Motherhood is a problematic question in that it prevents women from being more available for work, such as explained by E20: "motherhood becomes more complicated over time". Another important issue relates to the profile of women who may become mothers and married at 30 - as explained by E20. However, it can be assumed that not all women are passed over in hiring, but only those who are most likely to become a mother in a short time, as showed by the excerpt: "if you hire a man or a woman and you don't know his/her work yet, and both requested the same salary, and if the woman, for example, is around 30 and she is married, then we think: 'ah, if I hire her she will soon have a child' and women with children can be more complicated in the long run, so I think it affects the hiring".

In addition to the limitations regarding the availability and dedication to work, it was observed that motherhood is placed as a cause of higher costs for the organization, as explained by E57. She reports that the owner of the company where she works claims to prefer to hire men over women, given the higher costs caused by maternity leave. E47 already discussed the difficulties she faced when having children, to the extent that, as stated by E20, it results in reduced time availability for work. Here, less dedication by mothers happens because of the accumulation of multiple tasks. Another issue highlighted by E47 refers to the theme of the challenge in overcoming or dealing with too many obligations, that work with motherhood "is a lot for one person". However, motherhood is not only seen as a negative aspect by the interviewees. Many of them pointed to the maternal experience as helping learn to be more careful at work and developing the capacity to listen and act as conflict solvers in the organizational environment.

\section{Conclusion}

The objective of this research was to identify and analyze representations of femininity and masculinity as reported by women business executives. It intended to list their characteristics and attributes, to show those that are the most and least valued in the corporate world, as well as to consider the consequences of such representations for the women subjects. It did not intend to point out such femininities as social representations historically isolated to a specific sector of contemporary society, because such isolation would not exist concretely. Nevertheless, it considers that organizations are not only passive consumers of the gender representations that are externally produce by society. Organizations are not only consumers but also producers of masculinity and femininity.

First, it is noted that masculinity and femininity cannot be seen as biologically determined. Although some interviewees consider man as meaning male and woman as female, they clearly show in their speeches that women have masculinities and femininities at the same time. Thus, in this research women were not treated as meaning female, because women do not only consume and produce femininity, but also consume and produce masculinities and vice versa. Thus, as noted by Butler (2003) we cannot consider that sex is related to biology and gender represents culture. Both sex and gender are socially and historically constructed and both belong to the cultural order. 
Therefore, masculinity and femininity do not represent opposite poles to each other and they are not self-exclusive. The masculine includes the feminine and feminine includes masculine, as well the production of masculinity and femininity are directly related and mutually dependent. However, it can be said that masculinity is a cultural product highly valued in society by both men or women executives. In this sense, there are various forms of masculinity and femininity and individuals who exhibit masculine characteristics valued and viewed as hegemonic in a particular historical moment and cultural context have greater chances of acceptance and professional growth. A fact confirmed by the representation that the executives interviewed presented in their responses defining what is an executive.

It is noteworthy that in spite of the recovery of a hegemonic masculinity, women executives participating in this study did not show in their speech that there is an essential representation of masculinity, and they assert that some male characteristics can be at the same time positive and negative attributes concerning work performance. For example, rationality and logic, when extreme, may produce less dynamism and loss of sensitivity that prevents him/her from perceiving some conflict situations, and pragmatism may lead to disrespect and dehumanization. Characteristics considered feminine by the executives, such as flexibility, carefulness and conflict resolution, selfcontrol, and the ability to be organized are also valued. However, in the same way as masculinity, female characteristics may also act in a negative way, for example, an excess of sensitivity.

Finally, masculinity and femininity are not static entities, nor do they have an essence, they are a historical and cultural products always under construction. Moreover, there are other forms of gender expression beyond the masculine and feminine, these forms break the binary conception of gender and that should be explored in future organizational research.

Likewise, it is noteworthy that, although the strengthening of certain attributes regarded as typically feminine aim at an increased appreciation for the value of women in the work universe - and hence greater insertion and less problematic ascension - this too reproduces the prejudice detected in society. Thus, it is important to emphasize that there is no stereotype that is not excluding and that, therefore, does not forward and reaffirm certain social inequalities. For future research it is important to study intersectionality to better understand the heterogeneity related to gender aspects and investigations that not only focus on the phenomenon of motherhood, but also how fatherhood affects managers.

\section{References}

Adler, P., Forbes, L., \& Willmott, H. (2007). Critical management studies. Academy of Management Annals, 1(1), 119-179.

Alonso, S. L. (2002). Figuras clínicas do feminino no mal-estar contemporâneo. São Paulo: Escuta.

Bairley, M. M. (2012, June). Development and validation of perceived intersectionality of race, gender and sexual orientation scale (P-INTER) for social change workers. Proceedings of the Biennial International Interdisciplinary Conference Gender, Work \& Organization, Staffordshire, UK, 7.

Beauvoir, S. (2009). O segundo sexo: a experiência vivida (2a ed., S. Milliet, Trad.). Rio de Janeiro: Nova Fronteira. (Obra original publicada em 1967)

Bobbitt-Zeher, D. (2011). Gender discrimination at work: connecting gender stereotypes, institutional policies, and gender composition of workplace. Gender \& Society, 25(6), 764-786. doi: $10.1177 / 0891243211424741$

Bourdieu, P. (2007). A dominação masculina (5a ed., M. H. Kühner, Trad.). Rio de Janeiro: Bertrand Brasil. 
Braidotti, R. (2002). Cyberfeminism with a difference. In C. L. Mui \& J. S. Murphy (Eds.), Gender struggles: practical approaches to contemporary feminism (pp. 347-357). Lanham: Rowman \& Littlefield.

Bruschini, C., \& Puppin, A. B. (2004). Trabalho das mulheres executivas no Brasil no final do século XX. Cadernos de Pesquisa, 34(121), 105-138. doi: 10.1590/S0100-15742004000100006

Butler, J. (2003). Problemas de gênero: feminismo e subversão da identidade. Rio de Janeiro: Civilização Brasileira.

Calás, M. B., \& Smircich, L. (1999). Do ponto de vista da mulher: abordagens feministas em estudos organizacionais. In S. R. Clegg, C. Hardy, \& W. R. Nord (Orgs.), Handbook de estudos organizacionais (pp. 277-329). São Paulo: Atlas.

Cappelle, M. C. A., \& Melo, M. C. O. L. (2010). Mulheres policiais, relações de poder e de gênero na Polícia Militar de Minas Gerais. Revista de Administração Mackenzie, 11(3), 71-99. doi: 10.1590/S1678-69712010000300006

Cavazotte, F. S. C. N., Oliveira, L. B., \& Miranda, L. C. (2010). Desigualdade de gênero no trabalho: reflexos nas atitudes das mulheres e na sua intenção de deixar a empresa. Revista de Administração da Universidade de São Paulo, 45(1), 70-83.

Collinson, D. L. (1992). Managing the shopfloor: subjectivity, masculinity and workplace culture. Berlin: Walter de Gruyter.

Corrêa, A. M. (2004). O assédio moral na trajetória de mulheres gerentes (Master Dissertation). Centro de Pós-Graduação e Pesquisa em Administração, Faculdade de Ciências Econômicas, Universidade Federal de Minas Gerais, Belo Horizonte, MG, Brasil.

Cramer, L. (2009, setembro). Relações de Gênero, poder e profissão em organizações hospitalares: um enfoque sócioconstrucionista. Anais do Encontro Nacional da Associação Nacional de PósGraduação e Pesquisa em Administração, São Paulo, SP, Brasil, 33.

Cramer, L., Brito, M. J., \& Cappelle, M. C. (2004). Relações de gênero no espaço organizacional. Lavras: UFLA.

Davel, E. P. B., \& Vasconcelos, J. G. M. (1997). Gerência e autoridade nas empresas brasileiras: uma reflexão histórica e empírica sobre a dimensão paterna nas relações de trabalho. In F. C. P. Motta \& M. P. Caldas (Orgs.), Cultura organizacional e cultura brasileira (pp. 94-110). São Paulo: Atlas.

Dreyfus, H. L., \& Rabinow, P. (1995). Michel Foucault: beyond structuralism and hermeneutics. Chicago: University of Chicago Press.

Eccel, C. S., \& Grisci, C. L. I. (2009, setembro). Trabalho e gênero: a produção de masculinidades na perspectiva de homens e mulheres. Anais do Encontro Nacional da Associação Nacional de Pós-Graduação e Pesquisa em Administração, São Paulo, SP, Brasil, 33.

Ekenstam, C., Johansson, T., \& Kuosmanen, J. (2001). Cracks in the facade: masculinities in transition. Stockholm: Gidlunds.

Elsesser, K. M., \& Lever, J. (2011). Does gender bias against female leaders persist? Quantitative and qualitative data from a large-scale survey. Human Relations, 64(12), 1555-1578. doi: $10.1177 / 0018726711424323$

Figueiredo, L. (2002). Mulheres nas Minas Gerais. In M. D. Priore (Org.), História das mulheres no Brasil (6a ed., pp. 141-188). São Paulo: Contexto. 
Foucault, M. (2003a). A ordem do discurso. São Paulo: Edições Loyola.

Foucault, M. (2003b). Diálogo sobre o poder. In M. Foucault (Ed.), Estratégia, poder-saber (pp. 253266). Rio de Janeiro: Forense Universitária.

Foucault, M. (2004). Microfísica do poder. Rio de Janeiro: Edições Graal.

Freitas, M. E. (2001). Assédio moral e assédio sexual: faces do poder perverso nas organizações. Revista de Administração de Empresas, 41(2), 8-19. doi: 10.1590/S0034-75902001000200002

Gardiner, J. K. (2004). Men, masculinities, and feminist theory. In S. Kimmel, J. Hearn, \& R. W. Connell (Eds.), Handbook of studies on men \& masculinities (pp. 35-50). London: Sage Publications.

Gill, R. (2002). Discourse analyses. In M. W. Bauer \& G. Gaskell (Eds.), Qualitative researching with text, image and sound (pp. 244-270). London: Sage.

Gilligan, C. (1982). In a different voice: psychological theory and women's development. Cambridge: Harvard University Press.

Goldenberg, M. (2002). A arte de pesquisar: como fazer pesquisa qualitativa em Ciências Sociais. Rio de Janeiro: Editora Record.

Gregolin, M. R. V. (2004). O enunciado e o arquivo: Foucault (entre)vistas. In V. Sargentini \& P. Navarro-Barbosa (Orgs.), Foucault e os domínios da linguagem (pp. 23-44). São Carlos: Claraluz.

Halberstam, J. (1998). Female masculinity. Durham: Duke University Press.

Hansen, L. L. (2002). Rethinking the industrial relations tradition from a gender perspective: an invitation to integration. Employee Relations, 24(2), 190-210. doi: $10.1108 / 01425450210420910$

Hassard, J., Holliday, R., \& Willmot, H. (2000). Introduction: the body and organization. In J. Hassard, R. Holliday, \& H. Willmot (Eds.), Bodies and organization (pp. 2-13). London, Thousand Oaks, New Delhi: Sage Publications.

Hirata, H. (2002). Nova divisão sexual do trabalho? Um olhar voltado para a empresa e a sociedade. São Paulo: Boitempo.

International Labor Organization. (2008). Relatório global sobre discriminação no trabalho e desigualdades e discriminação no mercado de trabalho brasileiro. Retrieved from http://www.oitbrasil.org.br/info/downloadfile.php?fileId=133

Irigaray, L. (1985). Specutum of the other woman. New York: Cornell University Press.

Jerusalinsky, A. (2005). Qual o sexo de Oscar Wilde? In Associação Psicanalítica de Porto Alegre. Masculinidade em crise (pp. 15-29). Porto Alegre: APPOA.

Kanan, L. A. (2010). Poder e liderança de mulheres nas organizações de trabalho. Revista Organizações \& Sociedade, 17(53), 243-257.

Louro, G. L. (1997). Gênero, sexualidade e educação: uma perspectiva pós-estruturalista. Petrópolis: Vozes.

Louro, G. L. (2000). Corpo, escola e identidade. Educação e Realidade, 25(2), 59-76.

Louro, G. L. (2008). Gênero, sexualidade e educação: uma perspectiva pós-estruturalista. Rio de Janeiro: Vozes. 
Mavin, S., Bryans, P., \& Waring, T. (2004). Unlearning gender blindness: new directions in management education. Management Decision, 42(3/4), 565-578. doi: $10.1108 / 00251740410522287$

Melo, M. C. O. L. (2001, maio). Gerência feminina no setor bancário brasileiro: habilidades diferenciadas e desafios específicos. Anais da Assembléia do Conselho Latino-Americano de Escolas de Administração, México, México, 36.

Melo, M. C. O. L. (2003, dezembro). A gerência feminina em setores industrial e bancário: o conservadorismo internalizado versus o moderno em construção. Proceedings of the International Conference of Iberoamerican Academy of Management, São Paulo, SP, Brasil, 3.

Merrick, B. G. (2002). The ethics of hiring in the new workplace: men and women managers face changing stereotypes discover correlative patterns for success. Competitiveness Review, 12(1), 94-114. doi: 10.1108/eb046437

Nader, M. B. (2002, novembro). Mudanças econômicas, mulher e casamento em Vitória. 1970-2000. Proceedings of the Associação Brasileira de Estudos Populacionais, Ouro Preto, MG, Brasil, 13.

Natividade, D. R. (2009). Empreendedorismo feminino no Brasil: políticas públicas sob análise. Revista de Administração Pública, 43(1), 231-256. doi: 10.1590/S0034-76122009000100011

Newman, S. (2005). Power and politics in poststructuralist thougth: new theories of the political. London: Routledge.

Nogueira, C. (2001). Feminismo e discurso do gênero na psicologia social. Psicologia \& Sociedade, 13(1), 107-128.

Oksala, J. (2011). How is feminist metaphysics possible? A Foucauldian intervention. Feminist Theory, 12(3), 281-296. doi: 10.1177/1464700111417667

Oliveira, N., Oliveira, R., \& Dalfior, S. (2000, setembro). Gênero e novas perspectivas de trabalho: um Estudo Junto a Mulheres Gerentes de Atendimento no Banco do Brasil. Anais do Encontro Nacional da Associação Nacional de Pós-Graduação e Pesquisa em Administração, Florianópolis, SC, Brasil, 24.

Oliveira, Z. L. C. (2005). A provisão da família: redefinição ou manutenção dos papéis? In C. Araújo \& C. Scalon (Orgs.), Gênero, família e trabalho no Brasil (pp. 123-147). Rio de Janeiro: FGV.

Plummer, K. (2004). Male sexualities. In M. S. Kimmel, J. Hearn, \& R. W. Connell (Eds.), Handbook of studies on men \& masculinities (pp. 178-195). California: Sage Publications.

Potter, J. (1996). Discourse analysis and constructionist approaches: theoretical background. In J. Richardson (Ed.), Handbook of qualitative research methods for psychology and the social sciences (pp. 125-140). Leicester: British Psychological Society.

Ragins, B. R., Towsend, B., \& Mattis, M. (1998). Gender Gap in the executive suite: CEOs and female executives report on breaking the glass ceiling. Academy of Management Executive, $12(1), 28-42$.

Rodriguez, J., Rocha-Lawton, N., \& Gomez, C. (2012, June). Theorising Intersectionality in International Business Management. Proceedings of the Biennial International Interdisciplinary Conference Gender, Work \& Organization, Staffordshire, England, UK, 7.

Rubin, G. (1984). Thinking sex: notes for a radical theory of the politics of sexuality. In C. S. Vance (Ed.), Pleasure and danger: exploring female sexuality (pp. 3-44). London: Routledge. 
Scott, J. W. (1986). Gender: a useful category of historical analysis. The American Historical Review, 91(5), 1053-1075. doi: 10.1086/ahr/91.5.1053

Scott, J. W. (1992). História das mulheres. In P. Burke (Org.), A escrita da história: novas perspectivas (pp. 63-95). São Paulo: Unesp.

Scott, J. W. (1998). A invisibilidade da experiência. Projeto História, 16(1), 297-325.

Sedgwick, E. K. (2008). Epistemology of the closet. Berkeley: University of California Press.

Segnini, L. R. P. (1997). Aspectos culturais nas relações de gênero e a questão da produtividade em tempos de trabalho flexível e qualidade total. In F. C. P. Motta \& M. P. Caldas (Orgs.), Cultura organizacional e cultura brasileira (pp. 184-200). São Paulo: Atlas.

Silveira, N. S. P. (2009, setembro). Entendendo a experiência de inclusão-exclusão de mulheres em cargos de alta gerência. Anais do Encontro Nacional da Associação Nacional de PósGraduação e Pesquisa em Administração, São Paulo, SP, Brasil, 33.

Smith, B. G. (2003). Gênero e História: homens, mulheres e a prática histórica. Bauru, SP: Edusc.

Souza, E. M., Corvino, M. M. F., \& Lopes, B. C. (2011, novembro). Uma análise dos estudos sobre o feminino e as mulheres na área de administração: a produção científica brasileira entre 2000 a 2010. Anais do Encontro de Gestão de Pessoas e Relações de Trabalho da ANPAD, João Pessoa, PB, Brasil, 3.

Tanure, B., Carvalho, A., Neto, \& Andrade, J. O. (2007). Sucesso e (in)felicidade do executivo. São Paulo: Campus.

Thiollent, M. J. M. (1987). Crítica metodológica, investigação social e enquete operária. São Paulo: Polis.

Vilas Boas, L. H. B., Paula, A., Neto, \& Cramer, L. (2003). Relações de gênero nas organizações: um estudo no setor de vendas de veículos. Revista de Administração, 38(3), 219-229.

Wittig, M. (1985). The mark of gender. Feminist Issues, 5(2), 3-12. doi: 10.1007/BF02685575 